uchebnyk dlya stud. vyssh. ucheb. zaved. [Mathematics: a textbook for students of higher educational institutions]. Moscow, $320 \mathrm{p}$. [in Russian].

9. Tyhonenko, A. V. (2009). Yzuchenye ponyatyya velychyny $v$ nachalnoj shkole [Learning the concept of magnitude in elementary school]. Taganrog, 268 p. [in Russian].

10. Tyhonenko, A., Sarienko, V. \& Chaichenko V. et al. (2018). Velychyny u pochatkovi shkoli : navch.-metod. posibnyk [The values of the cob schools: the fore-method. ambassador]. Slovyansk, 152 p. [in Ukrainian].

11.Urban M.A. (2009). Izuchenie massy i sistemy edinits izmereniya massy na osnove obshchey dlya gruppy osnovnykh velichin modeli [Study of the mass and the system of units of mass measurement onthe basis of the total for the group of basic values]. Primary School, No. 11, pp. 22 - 28. [in Russian].

Стаття надійшла до редакції 12.04.2019

УДК 378.091 .39

DOI:

Ірина Савеліхіна, кандидат медичних наук, доиент кафедри фтизіатрії і пульмонології з курсом професійних хвороб ДВНЗ “Івано-Франківський начіональний медичний університет”

\title{
САМОСТІЙНА РОБОТА СТУДЕНТІВ ЯК ОСНОВА ПІЗНАВАЛЬНОЇ ДІЯЛЬНОСТІ У ФОРМУВАННІ ВИСОКОКВАЛІФІКОВАНИХ ФАХІВЦІВ
}

У статті обговорюється питання організаиії самостійної роботи студентів з англомовною формою навчання в медичному вузі. Звертається увага на методичні підходи до ї̈ вдосконалення, спрямовані на підвищення якості підготовки лікарів. Останні роки у багатьох медичних закладах вищої освіти Украӥни студенти, інших держав, мають можливість здобути вищу освіту англійською мовою. Така форма навчання є прогресивною та привабливою для великого числа студентів іноземців з різних країн світу.

Ключові слова: самостійна робота; медицина; студенти іноземиі.

Jim. 14.

Iryna Savelikhina, Ph.D.(Medicine), Associate Professor of the Phtisiology and Pulmonology with the Course of Occupational Diseases Department, SHEE "Ivano-Frankivsk National Medical University”

\section{INDEPENDENT WORK AS THE BASIS OF COGNITIVE ACTIVITY IN THE FORMATION OF HIGHLY QUALIFIED SPECIALISTS}

The article discusses the organization of independent work of foreign students. Attention is drawn to the methodological approaches of independent work perfection directed towards increasing the training level of doctors.

Higher education plays an important role in ensuring the training of competent and competitive professionals. Recently, in many medical higher educational institutions of Ukraine, students from other countries have the opportunity to obtain higher education in English. This form of training is quite progressive and attractive for a large number of foreign students from different countries of the world. In modern didactics, independent work of students is considered, on the one hand, as a type of educational work carried out without direct intervention, but under the guidance of a teacher, and on the other, as a means of engaging students into independent cognitive activity, developing their methods of organizing such activity. The effect of independent work of students can be obtained only when it is organized and implemented in the teaching and educational process as an integrated system, permeating all the stages of teaching students in high school. The training of skilled specialists that has the modern theoretical and practical skills, as well as the ability and desire for self-improvement, is the ultimate goal of any pedagogical process. Therefore, the main task of teaching medicine, in particular pulmonology, is the development of clinical thinking by students through the synthesis of profound theoretical knowledge, practical skills and clinical experience.

For the effective organization of independent work of students, the selection of educational material is of great importance. Tasks must be selected based on their practical use in the future profession. The teacher must take into account the substantive content of the disciplines, the level of theoretical preparedness of students, the availability of textbooks in the library collection and the specifics of the social pedagogue's professional activities. Properly organized work stimulates interest, activity, mental activity.

Keywords: independent work; medicine; foreign students.

засвоєнні та поглибленні знань, розвитку ключових компетенцій, як засіб активізації учнів, що $\epsilon$ важливим для формування навичок 


\section{САМОСТІЙНАРОБОТА СТУДЕНТІВ ЯК ОСНОВАПІЗНАВАЛЬНОӤ ДІЯЛЬНОСТІ У ФОРМУВАННІ ВИСОКОКВАЛІФІКОВАНИХ ФАХІВЦІВ}

самоорганізації та забезпечення розвитку особистості в цілому. Сформоване в останні роки нове уявлення про цінності професійного освіти вивело на перший план розвиток особистості, іiі саморозвиток і самореалізацію в професії, в тому числі за допомогою самостійної роботи [9].

В даний час актуальними стають вимоги до особистих якостей сучасного студента - вмінню самостійно поповнювати і оновлювати знання, вести самостійний пошук необхідного матеріалу, бути творчою особистістю. 3'являється нова мета освітнього процесу-виховання компетентної особистості, орієнтованої на майбутнє, здатної вирішувати типові проблеми і завдання виходячи 3 набутого навчального досвіду і адекватної оцінки конкретної ситуації [3]. Вирішення цих завдань неможливе без підвищення ролі самостійної роботи студентів над навчальним матеріалом, посилення відповідальності викладача за розвиток навичок самостійної роботи, за стимулювання професійного зростання студентів, виховання їх творчої активності та ініціативи.

Аналіз останніх наукових досліджень та публікацій. У медичному вузі самостійній роботі завжди відводилася важлива роль $[1-3$, 5]. Професія лікаря, мабугь, як ніяка інша, вимагає вміння брати на себе відповідальність, швидко приймати рішення і передбачити їх наслідки [1, 11 - 13]. Самостійність особистості, перш за все самостійність в мисленні і судженнях - запорука можливості придбання цих умінь. Навички самостійної роботи, сформовані в студентські роки - це, без сумніву, “безцінний багаж” для всієї подальшої професійної діяльності [1; 3, 11 - 13]. На сучасному етапі в зв'язку з реалізацією компетентнісного підходу до навчання самостійна робота актуалізується і набуває особливого значення. Успішність навчання сьогодні багато в чому залежить від організації самостійної роботи студентів [6;8].

Самостійну роботу правильно розглядати скоріше як засіб залучення студентів у самостійну пізнавальну діяльність, засіб іiі логічної і психологічної організації $[6 ; 9 ; 11]$.

Таким чином, самостійна робота - це засіб навчання, яке:

- в кожній конкретній ситуації засвоєння навчального змісту відповідає дидактичній меті і задачі;

- формує у того, хто навчається на кожному етапі його руху від незнання до знання необхідний обсяг і рівень знань, навичок і умінь для вирішення певного класу пізнавальних завдань і відповідного просування від нижчих до вищих рівнів розумової діяльності;
- виробляє у них психологічну установку на самостійне систематичне поповнення своїх знань і вироблення умінь орієнтуватися в потоці наукової і громадської інформації при вирішенні нових пізнавальних завдань;

- $є$ найважливішим знаряддям педагогічного керівництва та управління самостійною пізнавальною діяльністю того, хто навчається в процесі навчання [4, 9].

Мета статті полягала у розширенні контенту самостійної роботи студентів 3 англомовною форою навчання при вивченні дисциплін на кафедрі фтизіатрії і пульмонології з курсом професійних хвороб.

Виклад основного матеріалу. Програма навчання студентів на кафедрі фтизіатрії і пульмонології з курсом професійних хвороб має на меті поглиблення знань, отриманих на теоретичних і клінічних кафедрах в процесі попереднього навчання, а також отримання нових знань щодо питань етіопатогенезу, клінічної картини, принципів діагностики та лікування захворювань дихальної системи. Студенти навчаються виявляти основні скарги хворого, збирати анамнез захворювання, проводити об'єктивне обстеження пацієнта, формувати план додаткового обстеження, інтерпретувати результати лабораторних та інструментальних методів діагностики 3 урахуванням вікових особливостей i семіотики захворювань, формулювати розгорнутий клінічний діагноз відповідно до сучасних класифікацій, обгрунтовувати його, проводити диференційну діагностику основних пульмонологічних захворювань.

Основною метою викладання дисципліни “Пульмонологія" на кафедрі фтизіатрії i пульмонології з курсом професійних хвороб є навчання студентів теоретичним основам пульмонології, прийомам обстеження пульмонологічних хворих і постановки діагнозу; формування у студентів клінічного мислення, здатності самостійно діагностувати пульмонологічну патологію, визначати тактику лікування і профілактику найбільш поширених пульмонологічних захворювань $[1-3,5]$.

Навчання іноземних студентів, без сумніву, має цілий ряд особливостей, обумовлених кінцевою метою навчання, умовами отримання освіти та проживання у новому незвичному етнокультурному середовищі, періодом адаптації, взаємовідносинами у групі та 3 викладачем. Відомо, що ефективність та якість отримання освіти існує лише у тісному взаємозв'язку з мотиваційно-цільовими установками студентів, які 
обумовлені формування взаємодії та спілкування урізних сферах, і насамперед у навчально-науковій $[1-4,14]$.

На кафедрі фтизіатрії і пульмонології з курсом професійних хвороб проходять навчання іноземні студенти 4, 5 та 6 курсів 3 англійською мовою викладання. Навчання англійською мовою допомагає студентам краще підготуватись до складання іспитів та роботі на батьківщині $[5,7]$.

Самостійна робота студентів на кафедрі фтизіатрії і пульмонології з курсом професійних хвороб являє собою єдність трьох форм: позааудиторної самостійної роботи, аудиторної самостійної роботи, що здійснюється під безпосереднім керівництвом викладача, та творчої роботи. У процесі вивчення пульмонології студенти 3 англомовною формою навчання лікувального факультету повинні освоїти методи клінічного обстеження хворих 3 різними формами пульмонологічної патології; ознайомитися 3 найважливішими сучасними методами дослідження (біохімічними, радіологічними, імуноферментними, рентгенологічними та ін.), навчитися інтерпретувати отримані дані і зіставляти їх з клінічними проявами хвороби; навчитися діагностувати найпоширеніші пульмонологічні захворювання і правильно оформляти діагноз з урахуванням сучасних класифікацій і номенклатури хвороб; навчитися діагностиці невідкладних станів в пульмонології і принципам надання допомоги на догоспітальному та госпітальному етапах; освоїти принципи лікування легеневих захворювань; ознайомитися 3 питаннями лікарсько-трудової експертизи.

Існують два основних напрямки побудови навчального процесу на основі самостійної роботи студентів - це активні форми самостійної роботи, в ході яких відбувається взаємодія викладача та студента і інтерактивні форми самостійної роботи, в ході яких відбувається взаємодія не тільки студента 3 викладачем, але i 3 іншими студентами одночасно $[7 ; 9 ; 11]$. Самостійна робота студента на заняттях під керівництвом викладача протікає в формі ділової взаємодії: студент отримує безпосередні вказівки, рекомендації викладача про організацію самостійної роботи, а викладач виконує функцію управління через облік, контроль і корекцію помилкових дій. Інтерактивні методи навчання дають подвійний ефект: навчальний і виховний. В ході навчання на циклі "пульмонологія" студент іноземець повинен сформувати i продемонструвати ряд загальнокультурних (здатність і готовність до логічного i аргументованого аналізу, публічного мовлення, ведення дискусії, редагування текстів професійного змісту, співпраці і вирішення конфліктів) і професійних компетенцій (здатність і готовність до формування системного підходу, аналізу медичної інформації, використання теоретичних знань і практичних умінь 3 метою вдосконалення професійної діяльності) [11 - 14].

Однією $з$ інтерактивних інноваційних форм самостійної роботи на кафедрі фтизіатрії i пульмонології з курсом професійних хвороб студентів $є$ конференція.

Студенти самостійно готують мультимедійні презентації по певних розділах відповідно до тематичного плану практичних занять. Комп’ютерна презентація складається 3 набору слайдів в логічній послідовності, що розкривають зміст всієї роботи. Даний вид роботи дозволяє розширити обсяг знань в області діагностики та лікування пульмонологічних захворювань, вчить студентів логічно і змістовно будувати виклад матеріалу.

Конференція має ряд переваг перед іншими інтерактивними формами і методами самостійної роботи:

- формується вміння описувати особливість даної нозології;

- формується вміння мобілізуватися;

- формується вміння виділяти головне;

- формується звичка публічних виступів;

- формується звичка аналізу отриманих даних;

- поглиблене вивчення заданої теми;

- дозволяє виявити прогалини в теоретичних знаннях;

Одним 3 найважливіших умов ефективності самостійної роботи студентів $є$ іiї контроль $[3,6$, 11 - 12]. Розуміння студентом суті реалізованої системи контролю самостійної роботи дисциплінує, вносить організованість і впорядкованість в навчальну діяльність, особливо для майбутнього лікаря. Загальною метою контролю самостійної роботи студентів $\epsilon$ отримання зворотного зв'язку про те, як відбувається навчальна діяльність студентів, попередження можливих помилок і упущень, своєчасне виявлення відхилень для недопущення подальшого зниження якості роботи [10; 12].

Контроль не просто має місце бути в цілісній моделі організації самостійної роботи майбутніх лікарів, а є невід'ємним етапом, що приносить значний обсяг інформації про рівень підготовки студентів і це основа для прийняття подальших рішень по коригуванню всього процесу навчання. Для студента це можливість закріпити знання, вміння і навички і тверезо оцінити свої можливості і професійну спроможність. 
Види контролю самостійної роботи:

- комп'ютерний поточний самоконтроль i контроль успішності на базі електронних навчальних тестів;

- участь в наукових студентських конференціях i семінарах.

- аналітичний розбір наукової публікації по темі.

У зв'язку з цим можна виділити умови, що забезпечують успішне виконання самостійної роботи:

1) вмотивованість навчального завдання;

2) чітка постановка пізнавальних задач;

3) алгоритм виконання роботи;

4) чітке визначення викладачем форм звітності, обсягу роботи, термінів ііі подання;

5) визначення видів консультаційної допомоги;

6) критерії оцінки;

7) види і форми контролю (контрольні роботи, тести, семінар і т. д.).

Методичне забезпечення самостійної роботи студентів включає в себе визначення форм і тематики самостійних робіт, формулювання мети і завдання кожної з них, розробка інструкцій або методичних вказівок, добірка навчальної, довідкової, методичної та наукової літератури. Розробка комплексу методичного забезпечення навчального процесу $є$ найважливішою умовою ефективності самостійної роботи студентів. До такого комплексу відносяться тексти лекцій, навчальні та методичні посібники, монографії, методичні розробки, тестові завдання, спірограми, рентгенограми, томограми.

Це дозволить організувати проблемне навчання, в якому студент $\epsilon$ рівноправним учасником навчального процесу $[1 ; 5 ; 9]$. При цьому навчальні посібники повинні виконувати не тільки інформаційну, але і організаційноконтролюючу і керуючу функції $[2 ; 6 ; 11 ; 14]$.

Критерії оцінки результатів самостійної роботи:

- Рівень освоєння навчального матеріалу.

- Уміння використовувати теоретичні знання при виконанні практичних завдань.

- Повнота отримання професійних компетенцій.

- Обгрунтованість і чіткість викладу відповіді на поставлене питання.

- Оформлення звітного матеріалу відповідно по заданим викладачем вимогам.

В цілому ж орієнтація навчального процесу на самостійну роботу і підвищення іiї ефективності передбачає, по-перше, збільшення числа годин на самостійну роботу студентів; по-друге, організацію постійних консультацій; по-третє, створення навчально-методичної та матеріальнотехнічної бази в вузах.

Висновки. Таким чином, ефективна організація самостійної роботи студентів медиків дозволить досягти основної її мети, а самепідвищення якості професійної підготовки фахівців вищої кваліфікації, спрямоване на формування знань, умінь, навичок, які вони могли б вільно і самостійно застосовувати в практичній діяльності.

\section{ЛIТЕРАТУРА}

1. Асеев А. А. Использование информационных технологий в преподавании фтизиопульмонологии в медицинском ВУЗе. Туберкулез и болезни легких. 2011. № 4.C. 41-46.

2. Білозір Л.І., Ільницький І. Г., Костик О. П. Інноваційні технології та методологія викладання фтизіатрії студентам з англомовною формою навчання в умовах євроінтеграції медичної освіти. Український пульмонологічний журнал. 2013. № 1. С. 52-56.

3. Биков В. Ю. Теоретико-методологічні засади створення і розвитку сучасних засобів та технологій навчання. Розвиток педагогічної і психологічної наук в Україні, 1992-2002 : зб. наук. пр. до 10/річчя АПН України / Академія педагогічних наук України. Ч. 2. Харків: “OBC", 2002. C. 182-199.

4. Запорожан В.М., Кресюн В.Й., Аряєв, М.Л., Чернецька О.В. Англомовне навчання як стимулятор якості освіти та міжнародних контактів. Медична освіта. 2011. № 2. С. 46-47.

5. Зіменковський Б. С. Ільницький, І. Г. Павленко М. Л. Особливості викладання фтизіатрії та пульмонології студентам з англомовною формою навчання. Матер. наук.-практ.конф. "Сучасні проблеми епідеміології, мікробіології та гігієни”. Львів, 2010. С. 249-254.

6. Извозчиков А. А., Извозчиков В. А., Тумалев А. В., Тумалева Е. Ф. Виртуальные экскурсии в гуманитарноориентированном образовании: постановка проблемы и метапедагогика. Наука и школа. 2001. № 1. С. 45.

7. Каратєєва С.Ю. Особливості викладання хірургічних дисциплін іноземним студентам. Буковинський медичний вісник. 2013. Том 17. № 1. C. 209-210.

8. Ковальчук Л.Є. Удосконалення самостійної роботи студентів - необхідна умова реалізації ідей Болонського процесу. Галищькийлікар: вісник. 2008. Т. 15. № 1. С. 79-81.

9. Москаленко В.Ф. Яворовський, О.П., Остапюк Л.І. Про шляхи удосконалення якості вищої медичної освіти в контексті вимог Болонського процесу. Науковий вісник Національного медичного університету ім. О.О. Богомольця. 2005. № 1-2. С. 106-111.

10. Колчина В.В., Коротких И.Н. Некоторые вопросы организации самостоятельной работы студентов медицинских вузов. Личность, семья и общество: вопросы педагогики и психологии: сб. ст. по матер. междунар. науч.-практ. конф. № 6(41). Новосибирск, 2014.

11. Одинцова, М. В., Лысенкова, А. В. Перминова Е. А. Организация самостоятельной работы студентов на младших курсах как фактор повышения эффективности обучения. Проблемы здоровья и экологии. 2013. №3 (37). С. 31-34.

12. Субботин А. В., Семенов, В. А., Этенко Д. А. 


\section{САМОСТІЙНА РОБОТА СТУДЕНТІВ ЯК ОСНОВАПІЗНАВАЛЬНОӤ ДІЯЛЬНОСТІ У ФОРМУВАННІ ВИСОКОКВАЛІФІКОВАНИХ ФАХІВЦІВ}

Формирование мотивации к самостоятельной образовательной деятельности студентов. Материалы IV учебно-методической конференции Кемеровской государственной медицинской академии. Кемерово, 2013. С. $44-46$.

13. Фесенко В.П., Бабелич, О. К., Бутирський О. Г. Деякі питання мовної підготовки іноземних студентів для вивчення клінічних дисциплін. Проблеми підготовки медичних та фармацевтичних кадрів в Україні. Матеріали доповідей науково-методичної конференції. Київ-Дніпропетровськ. 2001. С. 254-255.

14. Хамнуева Л. Ю., Погорелова И. М. Оптимизация самостоятельной работы студентов медицинского вуза. Система менеджмента качества: опыт и перспективы. 2015. №4. С. 33-37.

\section{REFERENCES}

1. Aseev, A. A. (2011). Ispolzovanie informatsionnykh tekhnologiy $\mathrm{v}$ prepodavanii ftiziopulmonologii $\mathrm{v}$ meditsinskom VUZe [The use of information technology in the teaching of phthisiopneumology at a medical university]. Tuberculosis and lung diseases. No. 4, pp. 4146. [in Russsian].

2. Bilozi, L.I., Ilnytskyi, I. H. \& Kostyk, O. P. (et al). (2013). [Innovative technologies and methodology of teaching phthysiology to students with English language education in the conditions of European integration of (2002).medical education]. Ukrainian pulmonary journal. No. 1, pp. 52-56. [in Ukrainian].

3. Bykov, V. Yu. Teoretyko-metodolohichni zasady stvorennia i rozvytku suchacnykh zasobiv ta tekhnolohii navchannia [Theoretical and methodological principles of creation and development of joint facilities and technologies of teaching]. Rozvytok pedahohichnoi i psykholohichnoi nauk v Ukraini 1992-2002 [Development of pedagogical and psychological sciences in Ukraine1992-2002]. Academy of Pedagogical Sciences of Ukraine. Part. 2. Kharkiv, pp. 182-199. [in Ukrainian].

4. Zaporozhan, V.M., Kresiun V.I., Ariaiev, M.L. \& Chernetska, O.V. (2011). Anhlomovne navchannia yak stymuliator yakosti osvity ta mizhnarodnykh kontaktiv [English-language learning as a stimulator for the quality of education and international contacts]. Medical education. No. 2, pp. 46-47. [in Ukrainian].

5. Zimenkovsky, B. S., Ilnytskyi, I. H. \& Pavlenko, M. L. (2010). Osoblyvosti vykladannia ftyziatrii ta pulmonolohii studentam $\mathrm{z}$ anhlomovnoiu formoiu navchannia [Peculiarities of Teaching Phthisiology and Pulmonology to Students with the English Language Form of Learning]. Mater. nauk.-prakt.konf. "Suchasni problemy epidemiolohii, mikrobiolohii ta hihiieny" - Proceedings of the Scientific and Practical Conference. "Modern problems of epidemiology, microbiology and hygiene". (pp. 249-254). Lviv. [in Ukrainian].

6. Izvozchikov, A. A., Izvozchikov, V. A., Tumalev, A. V. \& Tumaleva, Ye. F. (2001). Virtualnye ekskursii v gumanitarno-orientirovannom obrazovanii: postanovka problemy i metapedagogika [Virtual Excursions in Humanitarian. Oriented Education: Decisions and Problems of Metapedagogy]. Science and School. No. 1, p. 45. [in Russian].
7. Karateyeva, S.Yu. (2013). Osoblyvosti vykladannia khirurhichnykh dystsyplin inozemnym studentam [Peculiarities of Teaching Surgical Disciplines to Foreign Students]. Bukovinsky Medical Bulletin. Vol.17, No. 1 (65), pp. 209-210. [in Ukrainian].

8. Kovalchuk, L. E. (2008). Udoskonalennia samostiinoi roboty studentiv - neobkhidna umova realizatsii idei Bolonskoho protsesu [Improving students' independent work is a necessary condition for implementing the ideas of the Bologna Proces]. Galician doctor: the journal. Vol. 15, No. 1, pp. 79-81. [in Ukrainian].

9. Moskalenko, V.F., Yavorovskyi, O.P. \& Ostapiuk, L.I. (2005). Pro shliakhy udoskonalennia yakosti vyshchoi medychnoi osvity v konteksti vymoh Bolonskoho protsesu [On ways to improve the quality of higher medical education in the context of the requirements of the Bologna process]. Scientific Bulletin of the National Medical University named after. O.O. Bogomolets. No. 1-2, pp. 106-111. [in Ukrainian].

10. Kolchina, V.V. \& Korotkikh, I.N. (2014). Nekotorye voprosy organizatsii samostoyatelnoy raboty studentov meditsinskikh vuzov [Some questions of the organization of independent work of students of medical schools]. Lichnost, semya $i$ obshchestvo: voprosy pedagogiki $i$ psikhologii: sb. st. po mater. mezhdunar. nauch.-prakt. konf. - Personality, family and society: questions of pedagogy and psychology: Collection of articles Art of the Proceedings and Intern. Scientific-Practical conference. No. 6 (41). Novosibirsk. [in Russian].

11. Odintsova, M. V., Lysenkova, A. V. \& Perminova, Ye. A. (2013). Organizatsiya samostoyatelnoy raboty studentov na mladshikh kursakh kak faktor povysheniya effektivnosti obucheniya [Organization of independent work of students in undergraduate courses as a factor in increasing the effectiveness of training].Problems of Health and Ecology. No.3 (37), pp.31-34. [in Russian].

12. Subbotin, A. V., Semenov, V. A. \& Etenko, D. A. (2013). Formirovanie motivatsii k samostoyatelnoy obrazovatelnoy deyatelnosti studentov [Formation of motivation for independent educational activities of students]. Materialy IV uchebno-metodicheskoy konferentsii Kemerovskoy gosudarstvennoy meditsinskoy akademii - Proceedings of the IV Educational and Methodical Conference of the Kemerovo State Medical Academy. (pp. 44-46). Kemerovo. [in Russian].

13. Fesenko V.P., Babelych, O. K., Butyrskyi O. H. (2001). Deiaki pytannia movnoi pidhotovky inozemnykh studentiv dlia vyvchennia klinichnykh dystsyplin [Some issues of language training of foreign students for the study of clinical disciplines]. Problemy pidhotovky medychnykh ta farmatsevtychnykh kadriv v Ukraini. Materialy dopovidei naukovo-metodychnoi konferentsii - Problems of preparation of medical and pharmaceutical personnel in Ukraine. Proceedings of the reports of the Scientific-Methodical Conference. (pp. 254-255). KyivDnepropetrovsk. [in Ukrainian].

14. Khamnueva, L. Yu. \& Pogorelova, I. M. (2015). Optimizatsiya samostoyatelnoy raboty studentov meditsinskogo vuza [Optimization of the independent work of medical students]. Quality management system: experience and prospects. No.4, pp. 33-37. [in Russian].

Стаття надійшла до редакції 25.03.2019 